\title{
INVESTIGATION OF THE SHELF LIFE OF BANANA 'MAS' (Musa acuminata Colla) USING GAMMA IRRADIATION
}

\author{
NUR FARHATUL HUDA SOPI and MOHD ZULFADLI ADENAN* \\ Centre of Medical Imaging, Faculty of Health Sciences, Universiti Teknologi MARA (UiTM), \\ UiTM Kampus Puncak Alam, 42300 Bandar Puncak Alam, Selangor, Malaysia \\ ${ }^{*}$ E-mail: mohdzulfadli@uitm.edu.my
}

Accepted 8 November 2021, Published online 30 November 2021

\begin{abstract}
To investigate the shelf life of banana 'Mas' (Musa acuminata Colla) using gamma rays in Malaysia. An experimental study to investigate the shelf life of banana Mas using different doses of gamma radiation. Different doses will be given to each group of banana Mas which are 0 (untreated control), 0.4, 0.8 and $1.2 \mathrm{kGy}$. The irradiated groups were being irradiated by gamma radiation at the National University of Malaysia (UKM) using Gamma Cell 220 Excel Cobalt-60 source. The observation was performed on the physical changes of the sample such as peel colour, decay rate, and physiological weight loss. Findings have shown that the high dose of gamma radiation caused the darkening of the peel and accelerate the ripening process depend on the varieties of the bananas. Among all, group B (0.4 kGy) has the lowest PWL (Physiological Weight Loss) and decay rate when compared to the other groups. The result of the one-way ANOVA test on the weight loss was not statistically significant. The dose of $0.4 \mathrm{kGy}$ was the most effective one in delaying the ripening process for banana Mas when compared to the other group samples.
\end{abstract}

Key words: Banana, gamma irradiation, shelf life

\section{INTRODUCTION}

The advancement of technologies in the postharvest industry has allowed horticultural sectors to meet the global demand for fresh fruits and vegetables such as banana Mas (Musa acuminata Colla). The banana is one of the superior fruit, has a high productivity and good adaptability in moderate plains (Sunyoto et al., 2019). However, the bananas are perishable that metabolically active, undergoing ripening and senescence processes that must be controlled to delay ripening (Mahajan et al., 2014). The fresh banana produce is potentially contaminated by microbes and pathogens during cultivation, harvesting, transporting, packaging, storage and selling to the consumers which manifests a severe risk in food safety and decreases the shelf life of bananas (Abdullah et al., 2017). Therefore, it cannot be preserved for a long time after harvesting which contributes to the limitation in exporting bananas (Abdullah et al., 2017).
Food irradiation can provide a promising alternative treatment to increase the shelf life of banana Mas as it is better in terms of cost, efficacy and resulting negative impact compared to the other technologies. Gamma radiations have proved to be more effective than an x-ray, as it is non-thermal technology, legal, low cost, maintaining freshness, quality, nutrition and leaves no harmful residue (Handayani \& Permawati, 2017). The advantages of gamma irradiation compared to the other methods is it provides more efficient and homogenous penetration power in the tissue, short radiation time and does not increase the fruit temperature (Abdullah et al., 2017). It can increase the shelf life of a banana by eliminating pathogenic bacteria, disinfect fresh fruits and vegetables as a postharvest quarantine treatment and reduce or eliminate microorganisms (Abdullah et al., 2017). This study aims to evaluate the application of gamma irradiation as the preservation method and its effect on the shelf life of banana Mas.

* To whom correspondence should be addressed. 


\section{MATERIALS AND METHODS}

\section{Sample preparation}

The sample used in this experiment was 20 green banana Mas with the same colour index no. 1, obtained from the banana orchard at Rawang, Selangor. Bananas were separated into groups of five to six in one group. The samples were sealed in cellophane bags, divided into 4 groups which were 1 group non-irradiated (controlled) and 3 groups irradiated with different doses of gamma rays (Figure 1). Each group consists of 5 bananas. They were being washed with water and dried in a dry place with a controlled temperature of $25^{\circ} \mathrm{C}$.

\section{Gamma irradiation}

Gamma irradiation from Cobalt-60 radioisotopes is more preferable in food irradiation (Ikinci, 2019). Likewise this study, the non-irradiated group was labelled as $\mathrm{A}(0.0 \mathrm{kGy})$ while the irradiated groups were labelled as B (0.4 kGy), C (0.8 kGy) and D (1.2 $\mathrm{kGy}$ ). The irradiated group being irradiated by gamma radiation at the National University of Malaysia (UKM) using Gamma Cell 220 Excel Cobalt-60 source (Figure 2). After being irradiated, the fruits were stored in the laboratory room at UiTM Puncak Alam under normal room temperature. Bananas will be observed every day for 5 weeks and data for evaluation of peel colour, weight loss and decay rate will be collected.

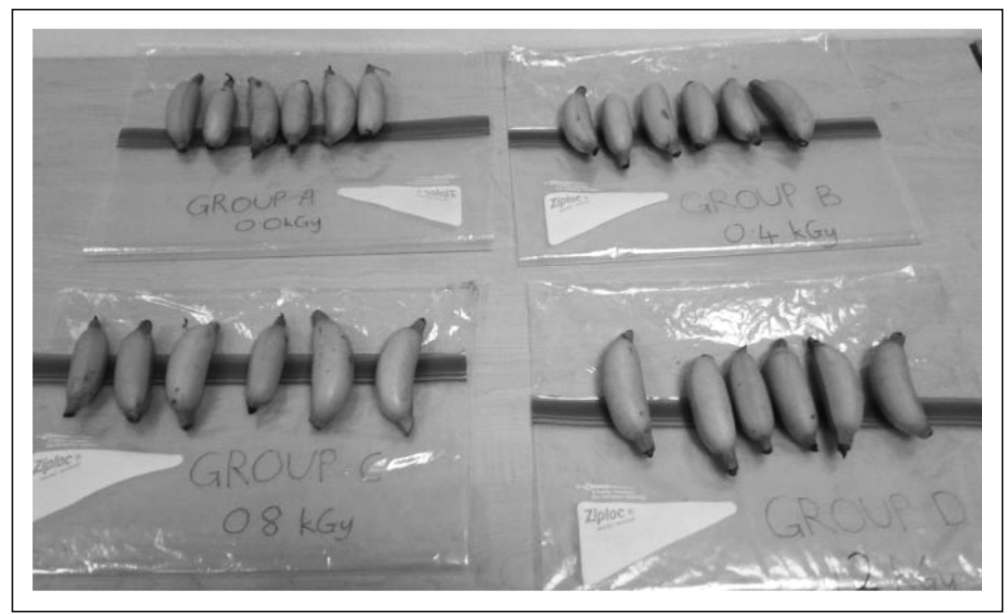

Fig. 1. The division of banana Mas into 4 groups with different doses of gamma irradiation.



Fig. 2. Gamma Cell 220 Excel S.N. 117R cobalt-60 with banana Mas placed inside the chamber of Gamma cell. 


\section{Peel colour}

The colour scale for banana ripening was used to monitor the colour of banana peel. The scale ranged from 1 to 7 , with values representing: (1) green (2) traces of yellow (3) more green than yellow (4) more yellow than green (5) yellow with green endings (6) completely yellow (7) yellow with slight brown specks and (8) yellow with more brown specks.

\section{Decay rate}

The decay of banana fruits during storage is observed and recorded every day for 5 weeks after irradiation. The decay is determined with a brown spot visible on banana Mas peel and the result is expressed as the percentage of decayed fruits (Abdullah et al., 2017).

$$
\text { Decay } \%=\frac{\begin{array}{c}
\text { Total number of } \\
\text { decayed banana }
\end{array}}{\begin{array}{l}
\text { Total number of } \\
\text { banana samples }
\end{array}} \times 100 \quad-\text { Equation } 1
$$

\section{Physiological weight loss (PWL)}

The weight loss is determined by weighing the initial mean mass $(\mathrm{g})$ and the final mean mass $(\mathrm{g})$ of the banana. The mean mass of each group of samples is recorded by measure the mass of each group three times for accurate reading. The results are expressed as the percentage of weight loss (PWL).

$$
P W L \%=\frac{\begin{array}{c}
\text { (initial weight }- \\
\text { final weight })
\end{array}}{\text { initial weight }} \times 100 \quad-\text { Equation } 2
$$

\section{RESULTS AND DISCUSSION}

\section{Peel colour}

According to Maduwanthi and Marapana (2017), fruit ripening is a genetically programmed process in fruits from unripe to ripe stage to produce attractive, edible fruit with an ideal blend of colour, taste, aroma and texture. In this study, the controlled group banana Mas shows the evolve of peel colour as the ripening process continue and the brown specks started to appear on the 7 days of storage. Meanwhile, the evaluation of peel colour changes of bananas irradiated at $0.4 \mathrm{kGy}, 0.8 \mathrm{kGy}$ and $1.2 \mathrm{kGy}$ were found to be unacceptable due to the darkening of the peel without affecting the pulp of the banana. However, the appearance of brown specks indicated as the final stage of ripening can be detected which then experiences advanced ripening with larger and darker brown. Within the 7 days of storage, irradiated banana Mas with a radiation dose of $0.8 \mathrm{kGy}$ and 1.2 kGy started to show brown spots on the peel colour of the banana while irradiated banana with $0.4 \mathrm{kGy}$ reached the final stage of ripening within 8 days of storage. The peel colour of all groups of irradiated banana Mas turns into dark brown without effect inside of the banana on the $3^{\text {rd }}$ day of the experiment.

The darkening of the banana peel is known as peel browning which happened when certain types of bananas are more sensitive during the fruit is handled (Ppo et al., 2016). It is a physiological disorder caused by stress-related at low temperature or relative humidity such as at the ambient temperature $\left(20^{\circ} \mathrm{C}\right)$ and low relative humidity $(50 \%)$. Based on the evaluation of the peel colour scale, the dose of $0.4 \mathrm{kGy}$ was the optimum dose to delay the stage of the ripening process when compared to the controlled group and irradiated group of $0.8 \mathrm{kGy}$ and $1.2 \mathrm{kGy}$. In contrast, one study proved that a different kind of banana irradiated at $1.0 \mathrm{kGy}$ may delay the ripening effect on peel colour, pulp to peel ratio or the levels of amines for about 7 days (Gloria and Adão, 2013). Another study from Jeong et al. (2016), stated that upon gamma irradiation, the bacterial cells result in substantial damage which then delays the changes of peel colour.

\section{Decay rate}

Decay rate analysis is presented in Tables 1, 2 and Figure 3. Tables 1 and 2 depicts the decay rate of all group samples of bananas and Figure 3 shows the line graph of the decay rate. The treated banana, group B with a dose of $0.4 \mathrm{kGy}$ lasted longer than

Table 1. The decay rate of all group samples of bananas

\begin{tabular}{ccccc}
\hline \multirow{2}{*}{ Days of storage } & \multicolumn{4}{c}{ Decay rate (\%) } \\
\cline { 2 - 5 } & Group A & Group B & Group C & Group D \\
\hline 2 & 0 & 0 & 0 & 0 \\
4 & 0 & 0 & 0 & 0 \\
6 & 0 & 0 & 0 & 0 \\
8 & 60 & 20 & 60 & 80 \\
10 & 80 & 40 & 100 & 100 \\
12 & 100 & 80 & - & - \\
14 & - & 100 & - & - \\
\hline
\end{tabular}


Table 2. Pearson correlation between the dose of gamma radiation and decay rate

\begin{tabular}{lccc}
\hline & & Dose of gamma radiation & Decay rate \\
\hline Dose of gamma radiation & Pearson Correlation & 1 & .674 \\
& Sig. (2-tailed) & N & 4 \\
Decay rate & Pearson Correlation & 4 & .674 \\
& Sig. (2-tailed) & .326 & 4 \\
\hline
\end{tabular}

Table 3. The weight loss and PWL of each group of banana Mas sample

\begin{tabular}{ccccc}
\hline Group & Initial mean mass $(\mathrm{g})$ & Final mean mass $(\mathrm{g})$ & Weight loss $(\mathrm{g})$ & Physiological weight loss $(\%)$ \\
\hline A & 34.2 & 18.6 & 15.6 & 45.61 \\
B & 35.4 & 20.0 & 15.4 & 43.50 \\
C & 36.6 & 19.2 & 17.4 & 47.54 \\
D & 37.4 & 18.4 & 19.0 & 50.80 \\
\hline
\end{tabular}

Table 4. ANOVA test

\begin{tabular}{lccccc}
\hline & Sum of Squares & df & Mean Square & F & Sig. \\
\hline Between Groups & 7.750 & 3 & 2.583 & .301 & .824 \\
Within Groups & 137.200 & 16 & 8.575 & & \\
Total & 144.950 & 19 & & & \\
\hline
\end{tabular}

the other group sample. This result was supported by Prakash (2019), who stated that the ripening process of the banana can be delayed by using a low dose of gamma radiation of 0.2-0.4 kGy. Research is done by Abdullah et al. (2017) also proved that nonirradiated bananas started to decay after two weeks of storage and irradiated bananas with a dose of $1.0 \mathrm{kGy}$ were remained healthy for up to 28 days that become superior one for controlling decay percent.

Thus, after two weeks, all the samples were completely decayed. Amongst all, group B at $0.4 \mathrm{kGy}$ can inhibit the process of the decay if compared to groups A, B and D. It is stated that the optimal dose for "Lactan', bananas when irradiated at the mature green stage is $0.25 \mathrm{kGy}-0.30 \mathrm{kGy}$. The ripening will accelerate when doses are below this range and the decay process will accelerate for the doses above it. The results of Pearson correlation in Table 2 revealed a non-significant and positive result ( $r=0.674$, $N=4, p=0.326$ ) with strong strength of correlation.

\section{Physiological weight loss}

Table 3 and Figure 4 shows the result of weight loss and PWL of the group samples. Among all 4 groups, group D with the higher gamma irradiation dose $(1.2 \mathrm{kGy})$ is the highest percentage of weight loss of $50.80 \%$. On the other hand, group B (0.4 kGy) showed the lowest percentage of weight loss with $43.50 \%$. Meanwhile, the percentage of weight loss for group A (0 kGy) and C (0.8 kGy) are $45.61 \%$ and $47.54 \%$ respectively. A one-way analysis of variance (ANOVA) test was calculated on the final weight between 4 groups of bananas as shown in Table 4 . The analysis was not significant with value of $\mathrm{F}(3,16)=0.301, p=0.824$. A research study stated that bananas experience the loss of weight during the ripening process due to decreases in carbohydrate (starch) and sugar content. The starch will change into fructose and glucose that are associated with the shrinkage of the mass and this change will continue until no more starch is available (Dwijananti et al., 2016). According to Prakash (2019), irradiation technology can affect the weight loss of postharvest fruits and vegetables depends on the type of food, amount of dose used for the treatment and the conditions of storage.

\section{CONCLUSION}

The findings indicate that there is no significant difference in the weight loss of banana Mas of all 4 groups. It is concluded that the dose of $0.4 \mathrm{kGy}$ 


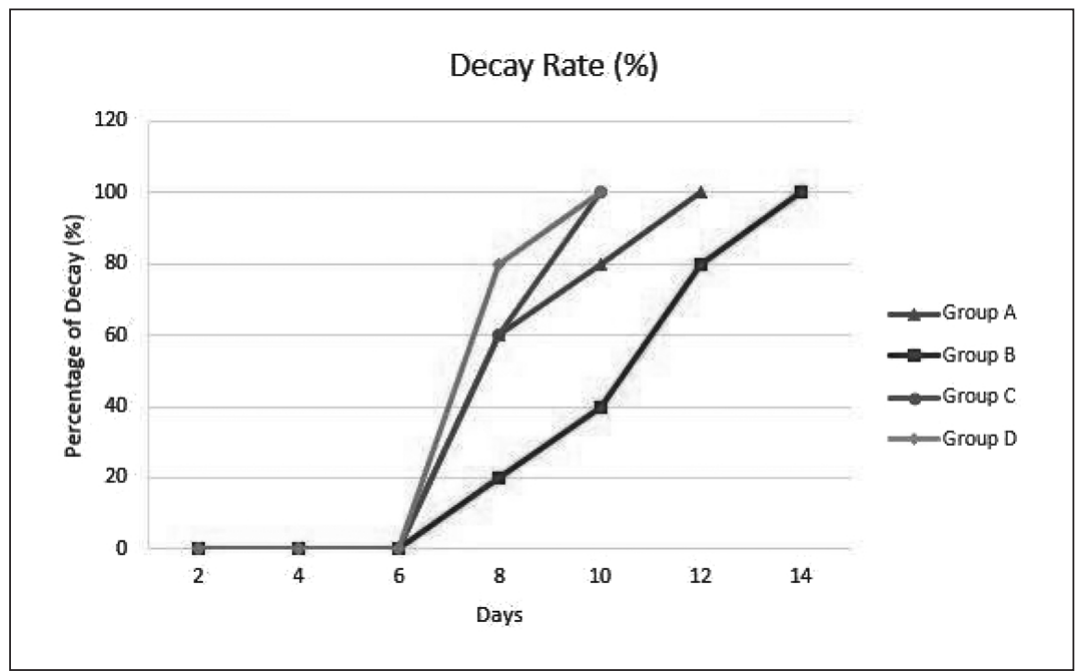

Fig. 3. The line graph of decay rate for each group of the sample.

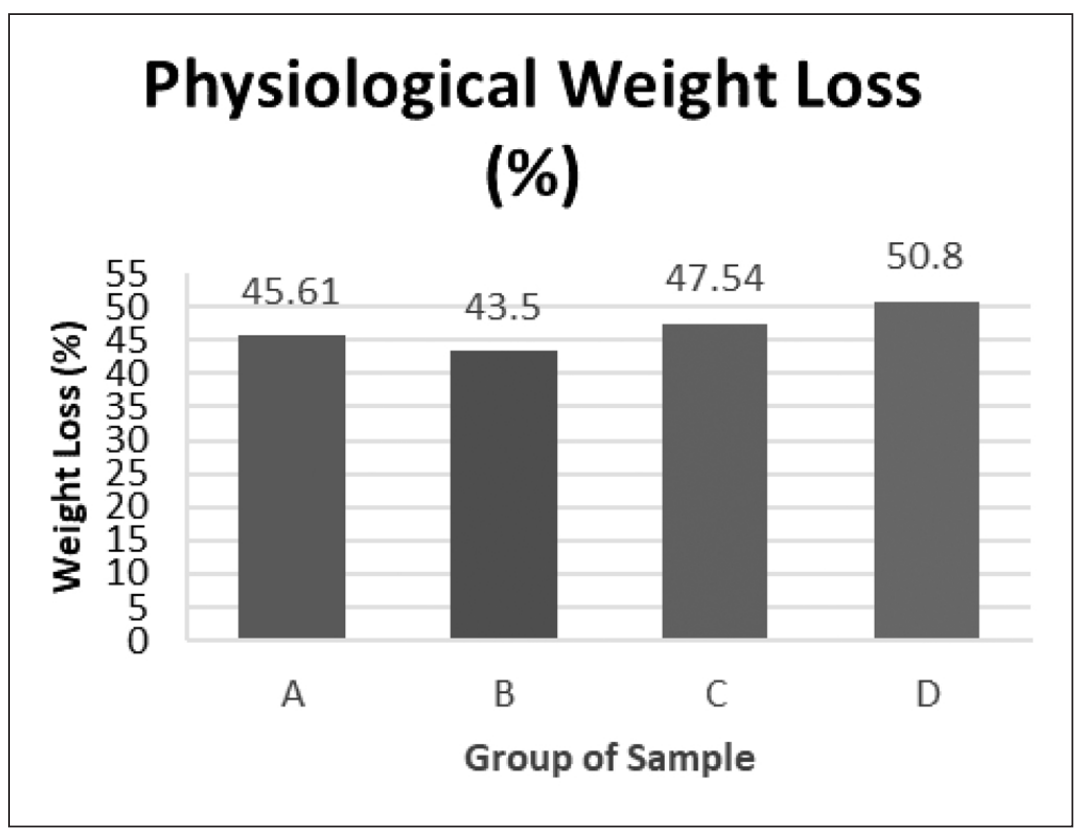

Fig. 4. The histogram of physiological weight loss of each group sample.

was the most effective one in delaying the ripening process for banana Mas when compared to the other group samples. Then, the optimum dose for gamma radiation depends on the types of bananas and this banana preservation technique provides opportunities to enhance the quality of the banana exports. For the future study, it is recommended to use a low range of gamma radiation dose about 0.3-0.5 kGy for evaluating the banana Mas. This is due to the peel of banana Mas is thin when compared to some of the banana varieties such as Dwarf Cavendish banana.

\section{ACKNOWLEDGEMENTS}

The authors are grateful to the authorities of the Center of Medical Imaging, Faculty of Health Sciences, Universiti Teknologi MARA, Puncak Alam campus and Center of Nuclear Technology, National University of Malaysia (UKM) for providing the laboratory facilities during the experiment. 


\section{REFERENCES}

Abdullah, R., Qaiser, H., Farooq, A., Kaleem, A., Iqtedar, M., Aftab, M. \& Naz, S. 2017. Evaluation of microbial potential and ripening behaviour of preclimacteric bananas following gamma irradiation. Bioscience Journal, 33(1): 57-65.

Dwijananti, P., Handayani, L., Marwoto, P. \& Iswari, R.S. 20_. Study of post-harvest Ambon

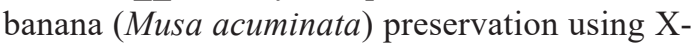
ray. 2016. Journal of Physics: Conference Series, 739: $1-5$.

Gloria, M.B.A. \& Adão, R.C. 2013. Effect of gamma radiation on the ripening and levels of bioactive amines in bananas cv. Prata. Radiation Physics and Chemistry, 87: 97-103.

Handayani, M. \& Permawati, H. 2017. Gamma irradiation technology to preservation of foodstuffs as an effort to maintain quality and acquaint the significant role of nuclear on food production to of Indonesia society. Energy Procedia, 127: 302-309.

Ikinci, A. \& Bolat, I. 2019. Meyve ve Sebzelerin Raf Ömürlerini Uzatmada Radyasyon Kullanımı. In: Uluslararasi Harran Multidisipliner Çalişmalar Kongresi. Şanlıurfa, Turkey. pp. 288-296.
Jeong, Rae-Dong \& Chu, E.-H. \& Lee, Gun Woong \& Park, J.M. \& Park, H.-J. 2016. Effect of gamma irradiation on Pseudomonas syringae pv. tomato DC3000 - Short Communication. Plant Protection Science, 52: 107-112.

Mahajan, P.V., Caleb, O.J., Singh, Z., Watkins, C.B. \& Geyer, M. 2014. Postharvest treatments of fresh produce. Philosophical Transactions of The Royal Society A, 372(2017): 20130309.

Maduwanthi, S.D.T. \& Marapana, R. 2017. Biochemical changes during ripening of banana: A review. International Journal of Food Science and Nutrition, 2(5): 166-169.

Ppo, A., Luyckx, A., Lechaude, M. \& Hubert, O. 2016. Banana physiological post-harvest disorders: A review. Food Processing and Technology, 3(1): 226-231.

Prakash, A. 2019. Irradiation of fruits and vegetables. Postharvest Technology of Perishable Horticultural Commodities, 2019: 563-589.

Sunyoto, M., Djali, M. \& Ibrahim, S.F. 2019. Study of gamma irradiation and its possibility to extend the banana 'Mas' (Musa acuminta Colla) shelf life. IOP Conference Series: Earth and Environmental Science, 309: 1-13. 